\title{
High temperature ultrasonic transducers: review
}

\author{
R. Kažys, A. Voleišis, B. Voleišienė
}

Prof. K. Baršauskas Ultrasound Institute, Kaunas University of Technology

Studentu st. 50,LT-51368 Kaunas, Lithuania,e-mail: rymantas.kazys@ktu.lt

\begin{abstract}
The problems of development of high-temperature ultrasonic transducers for modern science and technology applications are analysed. More than 10 piezoelectric materials suitable for operation at high temperatures are overviewed. It is shown that bismuth titanate based piezoelectric elements are most promisable. Bonding methods of piezoelectric elements to a protector and backing are discussed. Thermosonic gold-to-gold bonding is most modern and possesses unique features. Our achievements in this field are analysed in the context of world progress. In sol-gel and chemical vapour deposition technology bonding and sometimes coupling problems are avoided at all. Design peculiarities of the transducers are reviewed. Commercial sensors in the meanwhile are often characterized with poor performance in extreme conditions.
\end{abstract}

In conclusions recommendations for high temperature ultrasonic transducers design are formulated.

Keywords: ultrasonic transducer, high temperature transducers, piezoelectrics, bonding, acoustic coupling.

\section{Introduction}

Modern science and technology very often demand application of high temperature ultrasonic transducers. Two major requirements for ultrasonic measurements at high temperatures are: to possess transducers that themselves withstand the heat and to also to provide a suitable acoustic coupling between the sensitive element of the transducer and the object under a test.

First ultrasonic transducers for use at high temperatures have been described in literature since 1940 and were widely employed within nuclear power industries for a big variety of non-destructive testing (NDT) and nondestructive evaluation (NDE) applications. Ultrasonic methods are effective means to inspect the internal state of materials, both in laboratories and industrial environments. For instance, ultrasonic NDT of steel components in industrial plants is performed at temperatures up to $400^{\circ} \mathrm{C}$. Progress in material science has enabled to create a lot of advanced composites and engineering materials. Ultrasonic monitoring is often used to characterize these materials during manufacturing at elevated temperatures, for example, during polymer extrusion and curing processes of graphite/epoxy composites. Ultrasound Doppler velocimetry of hot melts flows is an important field of high temperature ultrasonic transducers applications. Until now, no velocity measuring technique for liquid metals flows is available commercially. Apart from high temperatures, wetting and corrosiveness are the main difficulties of the measurements in liquid metals. Wetting behaviour can be evaluated by means of ultrasonic technique. In this case a positive feature is ultrasound propagation in liquid metals without significant attenuation. Therefore, ultrasonic methods are promising for on-line monitoring of molten metal properties. Possibility of ultrasonic ranging and imaging in liquid metals is very important for establishment of quasi-visibility inside modern reactors, cooled by $\mathrm{Pb} / \mathrm{Bi}$ alloy [1-3]. Space exploration technology challenge requires new actuator and sensor designs. For example, there are no commercially available piezoelectric rotors for manipulators, operating in Venus. Its environment represents several extremes: high temperatures $\left(460{ }^{\circ} \mathrm{C}\right)$, high pressure $(9 \mathrm{MPa})$ and corrosiveness $[4,5]$.

Poor performance of commercial sensors at elevated temperatures is still a significant obstacle in many applications. This problem is associated with different thermal expansion of various sensor elements.

This review is devoted to a detailed survey of development and achievements in the field of ultrasonic high temperature transducers.

\section{Overview of piezoelectric elements suitable for high temperature conditions}

There are many ferroelectric/piezoelectric materials that possess high Curie temperatures however the piezoelectric response of these materials is generally low in comparison to PZT ceramics. We shall overview the following materials: lead zirconate-titanate PZT, modified PZT, bismuth titanate $\mathrm{Bi}_{4} \mathrm{Ti}_{3} \mathrm{O}_{12}$, modified bismuth titanate, lithium niobate $\mathrm{LiNbO}_{3}, \mathrm{LNN}$ based on $\mathrm{LiNbO}_{3}$, lead metaniobate $\mathrm{PbNb}_{2} \mathrm{O}_{6}$, modified lead titanate, modified lead metaniobate, galium orthophospate $\mathrm{GaPO}_{4}$, aluminum nitride AlN, BMT-PT, BS-PT, sol-gel sprayed films, as well as some commercially available high temperature ultrasonic transducers.

The lead zirconate-titanate PZT is the main widely used piezoelectric material in the lower temperature range: the Curie temperature $T_{\mathrm{C}}=350^{\circ} \mathrm{C}$; the recommended operation temperatures are up to $T_{0}=150 \div 200{ }^{\circ} \mathrm{C}$; the thickness mode coupling coefficient $k_{\mathrm{t}}=0.5$. Some modifications of PZT have somewhat higher Curie temperature, e.g. PZT-5a $T_{\mathrm{C}}=365^{\circ} \mathrm{C}, k_{\mathrm{t}}=0.45[6,7]$. The piezocomposite PZT may be used up to $180{ }^{\circ} \mathrm{C}$ [8].

The bismuth titanate $\mathrm{Bi}_{4} \mathrm{Ti}_{3} \mathrm{O}_{12}$ has a very high Curie temperature and consequently operating temperatures. This material exhibits a low dielectric constant, low dielectric losses and properties are stable up to very high temperatures. Sensitivity is lower than of the PZT. The bismuth titanate belongs to the group of sillenite structure- 
based ceramics $\left(\mathrm{Bi}_{12} \mathrm{MO}_{2}\right.$, where $\left.\mathrm{M}=\mathrm{Si}, \mathrm{Ge}, \mathrm{Ti}\right)$. The features of some commercially available materials are the following:

Pz45 (Ferroperm), $T_{\mathrm{C}}=500^{\circ} \mathrm{C}, k_{\mathrm{t}}=0.13[9,10]$; $[9,10]$

Pz46 (Ferroperm), $T_{\mathrm{C}}=650{ }^{\circ} \mathrm{C}, T_{\mathrm{o}}=500 \div 550^{\circ} \mathrm{C}, k_{\mathrm{t}}=0.20$

B8613 (Noliac), $T_{\mathrm{C}}=$ N.A., $T_{\mathrm{o}}=500^{\circ} \mathrm{C}, k_{\mathrm{t}}=0.23$ [4];

PzS90 (Seacor Piezoceramics), $T_{\mathrm{C}}=670^{\circ} \mathrm{C}, T_{\mathrm{o}}=500^{\circ} \mathrm{C}$ [11]; [11].

PzS96 (Seacor Piezoceramics), $T_{\mathrm{C}}=920^{\circ} \mathrm{C}, T_{\mathrm{o}}=700^{\circ} \mathrm{C}$

The modified bismuth titanate Kezite K15 (Piezo Technologies, Keramos) is a revolutionary piezoelectric ceramic developed for high temperature applications previously not possible. It has an extreme piezoelectric stability, its $T_{\mathrm{C}}=600^{\circ} \mathrm{C}, k_{\mathrm{t}}=0.15[12,13]$.

Lithium niobate $\mathrm{LiNbO}_{3}$ has the Curie temperature $1210^{\circ} \mathrm{C}, k_{\mathrm{t}}=0.30 \quad$ [7]. Unfortunately, at $600^{\circ} \mathrm{C}$ lithium niobate starts to lose oxygen to the environment, what makes it impossible to use [14].

Lithium niobate 1-3 connectivity composite material is made with pillars of $\mathrm{Z}$-cut crystal in a matrix of alumina cement $\mathrm{Al}_{2} \mathrm{O}_{3}$ (Cotronics Resbond 989). The composite material produced shorter pulses than a monolithic plate of lithium niobate, it can operate at temperatures above $400{ }^{\circ} \mathrm{C}[15]$.

The LNN is a piezoceramic newly developed by Ferroperm based on $\mathrm{LiNbO}_{3}$. The working temperature is a little higher than $\mathrm{LiNbO}_{3}\left(T_{\mathrm{o}}=650^{\circ} \mathrm{C}\right)$, sensitivity is higher as well; the pulse shape improves at high temperatures [16].

The lead metaniobate $\mathrm{PbNb}_{2} \mathrm{O}_{6}$ posseses the high Curie temperature of $540^{\circ} \mathrm{C}$, a low mechanical quality factor and is suitable as a sensitive element of a sensor. However, it is difficult to fabricate dense $\mathrm{PbNbO}_{6}$ ceramics that have good piezoelectric properties. Ceramics with a high density and a high piezoelectric effect were fabricated by adding various elements such as $\mathrm{Mn}$ and $\mathrm{Ca}$ to $\mathrm{PbNb}_{2} \mathrm{O}_{6}$ and by examining the sintering process [17]. The high Curie temperature warrants the use of $\mathrm{PbNb}_{2} \mathrm{O}_{6}$ up to $300^{\circ} \mathrm{C}$. This piezoelectric ceramic material has a good thermal shock resistance [18]. The thickness mode coupling coefficient is $k_{\mathrm{t}}=0.30$ [6].

The modified lead titanate Pz32 (Ferroperm) has the Curie temperature $400^{\circ} \mathrm{C}, \quad k_{\mathrm{t}}=0.43$, the operating temperature at the moment is non-available [9]. It has high mode cancellation compared to other solid solution piezoelectric materials such as zirconium titanates.

The modified lead metaniobate K-81, K-83 (Keramos) has $T_{\mathrm{C}}=570^{\circ} \mathrm{C}, k_{\mathrm{t}}=0.41$ and is intended for high temperature applications up to $300^{\circ} \mathrm{C}[7,13]$.

Galium orthophospate $\mathrm{GaPO}_{4}$ is a new piezoelectric material for a wide range of high technology applications. The sensitivity and a high thermal stability make it a very attractive choice for a wide range of uncooled high temperature applications up to $900^{\circ} \mathrm{C}$. $\mathrm{GaPO}_{4}$ belongs to the same point group as quartz. $\mathrm{Up}$ to $700^{\circ} \mathrm{C}$ the piezoelectric constant $d_{11}$ shows no measurable deviation from its room temperature value which is about twice that of quartz [19]. As compared with bismuth titanate its sensitivity is significantly lower.
Aluminum nitride AlN polycristalline ceramic film has no known Curie point. It is similar to quartz in that it is structurally piezoelectric and does not require poling. AlN ultrasonic transducers are capable of operation at temperatures exceeding $1100^{\circ} \mathrm{C}$. This material is a strong candidate for high frequency ultrasonic transducers as the deposition of very thin films is easily done. To date, ultrasonic transducers in the $10-100 \mathrm{MHz}$ range have been produced and tested [20]. Chemical vapor deposition (CVD) technique was developed to produce AlN layers on a suitable substrate. A good adherence is achieved on tungsten carbide and graphite [21]. The substrate must be electrically conductive [22]. Sensitivity of AIN is significantly lower than of the bismuth titanate.

A more detailed information about piezomaterials BMT-PT and BS-PT (TRS Technologies Inc) is not available. It is known, that BMT-PT is characterised by $T_{\mathrm{C}}=450^{\circ} \mathrm{C}, k_{\mathrm{t}}=0.44$, while BS-PT by $T_{\mathrm{C}}=400^{\circ} \mathrm{C}, k_{\mathrm{t}}=0.47$. Their piezoelectric activity is of the same order as PZT, while mechanical and electrical losses are about an order of magnitude higher. Dependencies presented in $[4,5]$ show their stable operation up to the Curie temperature.

The sol-gel based technology is a novel approach to deposit high-temperature ultrasonic transducer directly on steel substrates thus avoiding acoustic coupling problems. High Curie temperature ferroelectric crystals powders are incorporated in a sol-gel solution, which is sprayed onto the substrate at a room temperature. Multilayer coatings are used. After the thermal treatment, poling is performed using a corona discharge method. The layers obtained are up to $200 \mu \mathrm{m}$, typical rezonance frequencies are in the range $3.3-30 \mathrm{MHz}$, the working temperature is up to $500^{\circ} \mathrm{C}$. As a rule, two different piezoelectric materials are used in sol-gel solutions: one is responsible for high piezoelectricity, while another for a high Curie temperature. The typical piezoelectric combinations are the following: $\mathrm{LiNbO}_{3} / \mathrm{LiTaO}_{3}$ [23, 24], PZT/ $\mathrm{LiTaO}_{3}$ [25], $\mathrm{Bi}_{4} \mathrm{Ti}_{3} \mathrm{O}_{12} /$ PZT [26-28].

A new ceramics based on $\mathrm{LiNbO}_{3}$ was fabricated using only the sol-gel based technology. It is known, that $\mathrm{LiNbO}_{3}$ starts to lose oxygen at $600{ }^{\circ} \mathrm{C}$. An idea was to block oxygen loss by replacing some of the $\mathrm{Li}$ with another element. Sodium offers a better piezoelectric sensitivity than Li. An exaustive examination of the $\mathrm{Li} 1-\mathrm{xNaxNbO}_{3}$ family was provided with an atomic percentage of sodium between $0 \%$ and $25 \%$. The new piezoelectric material had no oxygen loss and unique performance was achieved. But there should be no illusions about the speed with which this new scientific knowledge is likely to be commercialized [14].

\section{Analysis of bonding techniques of piezoelectric elements to stainless steel protection layer and backing}

Three diferent concepts of acoustic coupling at high temperatures are known [16]: dry coupling (with a high pressure); liquid (fluid) coupling; solid coupling.

In a dry coupling a high quality surface finish is required. Very small airgaps $(>0.01 \mu \mathrm{m})$ between a piezoelectric element and a front protective layer 
substantially reduce the acoustic energy entering the material and pressures up to $300 \mathrm{MPa}$ are required to expel the air even at an interface between highly polished surfaces [29]. Dry coupling is impossible with the transducer $\lambda / 2$ membrane, as it can not withstand the necessary coupling pressure. Surface irregularities can cause deformations and failure of the piezoelement. Soft metal (best-gold) interlayer application makes easier the realisation of the method. It is problematic to keep constant the coupling pressure in the whole required temperature range. Over twenty years ago, Argone National Laboratories demonstrated a soft metal foil as an effective long-term ( $>5$ years) couplant in ultrasonic flowmeters, in experiments up to $600^{\circ} \mathrm{C}$ on liquid sodium [30]. It was used for clamp-on coupling of waveguide buffers. In tests of short duration a satisfactory economical couplant is an aluminum foil. For permanent coupling a gold foil is generally prefered. The foil usually is rolled and must be annealed, e.g. in an alcohol lamp flame. The optimal coupling pressure must be applied at higher temperatures as a metal foil couplant is not soft enough at a room temperature. It is reported the use of a metal foil for the coupling of ultrasonic energy between the AIN transducers and the object at elevated temperatures [31]. Dry coupling of a piezoelectric transducer with AISI-316 ultrasonic waveguide was used by us successfully and good experimental results were obtained $[1,3]$. The contacting surfaces of a piezoelement and a waveguide were flat polished to the optical quality. The soft gold foil was of $99.99 \%$ purity, $20 \mu \mathrm{m}$ thickness. The pressure at elevated temperatures was increased gradually and measured until maximal damping of the piezoelement was observed and the duration of the ultrasonic signal did not shorten further. Perfect signals were observed up to $410^{\circ} \mathrm{C}$ at the pressure $60-70 \mathrm{MPa}$. Dry coupling with thin $\lambda / 2$ or $\lambda$ membranes was not quite successful as the membrane bent when the applied pressure increased.

In a liquid coupling thin acoustical membranes can be used. However, in spite of numerous attempts an optimal coupling fluid, concerning corrosives properties especially, is not yet available. Liquid couplants can be devided into two groups: liquid at the room temperature (silicone oil, specialized high temperature couplants, etc); glass solders, which are solid at the room temperature and melt prior to operation.

Silicone oil as a couplant was used successfully up to $250{ }^{\circ} \mathrm{C}[8,18]$, but evaporated gradually. During a long lasting operation of the transducer the liquid couplant can flow out of the interfaces due to vibrations of a piezoelement. The chemical stability of this couplant is lost when the temperature increases for a longer period [8]. An original high temperature ultrasonic couplant is offered in [32]. It is non-flammable and consists of grease-like silicone fluid heavily filled with zinc oxide. The material was used in a nuclear reactor at radiation levels up to 50 $\mathrm{R} / \mathrm{h}$. The couplant material is capable of withstanding thermal cycling.

Specialized high temperature couplants must be used quickly since they tend to dry out or solidify and no longer transmit an ultrasonic energy. Couplant E (Ultratherm) is recommended for use between $260^{\circ} \mathrm{C}$ and $540^{\circ} \mathrm{C}$ [33]. It is reported, that couplants for continuous use (scanning) at the temperatures above $350^{\circ} \mathrm{C}$ are difficult to find [34]. In a higher temperature range a solid couplant material Sono 1100 Film [35] is designed to melt at the temperature $370^{\circ} \mathrm{C}$ and is intended for use up to $593^{\circ} \mathrm{C}$, but only for 15 seconds.

Internal acoustic coupling in principle may be accomplished with glass solder, which is fluid in the temperature range required. Low melting metals had to be excluded because they may cause short circuiting. The choices of the glass solder are made and balanced with respect to medium, chemical reactivity and compatibility, diffusion, evaporation, thermal expansion, mechanical behaviour under solidification, etc. Broad parametric studies were provided and glass solder "NaPoLi", consisting of sodium oxide, phosphor oxide and lithium oxide was selected with respect to its thermal expansion coefficient [16]. However, at higher temperatures the glass solder reacts chemically with the probe's components, except of platinum and gold. "NaPoLi" can be used as a coupling medium up to $500^{\circ} \mathrm{C}$. There are known nonalkaline glass solders (LG-K1, LG-K2), which are much less chemically reactive. Unfortunately, a good adhesion between the transducer elements is an unsolved problem, as $60 \%$ revealed adhesion problems [16]. The coupling began to emerge at a temperature $300{ }^{\circ} \mathrm{C}$, but was subjected to changes, which ceased at around $350^{\circ} \mathrm{C}$, where the probe showed its best sensitivity. It decreased later, and at $530^{\circ} \mathrm{C}$ no signal was observed. An unusual bonding material which is conductive and stable up to $600^{\circ} \mathrm{F}$ temperature and $50 \mathrm{R} / \mathrm{h}$ radiation is reported in [36]. It comprises four components: a carborane polysiloxane, a vehicle-solvent which will evaporate, a wetting agent and conductive materials. The bonding material has extremely stable ultrasonic signal properties.

In a solid coupling several approaches can be used: soldering; diffusion bonding; ultrasonic welding; cementing; epoxy bonding; sol-gel or CVD technology.

Compact and stable ultrasonic transducers for undersodium scanner were designed using crystal and transducer face soldering technology. A solder with the melting point $220^{\circ} \mathrm{C}$ was used. The transducers were tested in silicon oil at the temperature of $200{ }^{\circ} \mathrm{C}$ and were found to perform well [37]. At higher temperatures only a limited number of suitable soft solders are found. A solder should be elastic in order to compensate different temperature expansions of protector, backing and piezoelement; it should not dissolve thin electrodes of the piezoelement, etc. The commercially available $88 \mathrm{Au}-12 \mathrm{Ge}$ solder alloy offers the best opportunity for making dissimilar metal joints (the melting point $356{ }^{\circ} \mathrm{C}$ ). The $88 \mathrm{Au}-12 \mathrm{Ge}$ alloy is effective in relaxing residual stresses generated during thermal processing. It is ductile and suitable for the joints comprised of dissimilar metals having different thermal expansion properties [38].

There is known a soldering (solder $\mathrm{Ag}$ based, m.p. $\sim 500^{\circ} \mathrm{C}$ ) technology for the bonding of $\mathrm{LiNbO}_{3}$ crystal to the steel block using Ti foil interlayer [39]. In an integrated ultrasonic probe the piezoelement is welded to the rear end of the acoustic waveguide fabricated from a stainless steel foil [40]. 
There are known some attempts of diffusion bonding of a piezoelement. Los Alamos National Laboratory patented ultrasensitive ultrasonic transducer [41]. It is formed as a silver-to-silver diffusion bonded assembly of piezoelectric crystal, backing material and ceramic wear surface. Unfortunately, there is no information about its high temperature operation. The bonding can be carried out at the atmospheric pressure with silver sputtered pieces at temperatures over $150{ }^{\circ} \mathrm{C}$ and pressures about $50 \mathrm{MPa}$ depending on samples. However, at higher temperatures $\left(\mathrm{T}>0.5 \mathrm{~T}_{\mathrm{C}}\right)$ due to local stresses the cracks in the piezoelectric ceramics originate and develop just under the surface. For PZT type ceramics it happens at the temperatures higher than $170^{\circ} \mathrm{C}$ [42]. Honeywell provided PZT to PZT, PZT to metal bonding for piezoelectric motors. Silver-to-silver thermocompressive bonding took place in a light vacuum environment, at the temperature $<250{ }^{\circ} \mathrm{C}$ and pressures $10 \div 40 \mathrm{MPa}$ [43]. It is emphasized that the flatness of the samples and more consistent loading are very critical. The bonded samples were ultrasonically tested and showed good-looking bonds in the ultrasonic imaging. In an indium cold welding technology only a mild pressure is required to bond an extremely thin piezoelectric crystal to a saphire lens to achieve high ultrasonic transmission (NASA Lewis Research Center) [44]. Unfortunately, the indium melting temperature is only $156^{\circ} \mathrm{C}$.

For high temperature operation we provided bismuth titanate piezoelement bonding to the stainless steel protector using thermocompression gold-to-gold technology. The temperature was $400^{\circ} \mathrm{C}$, the static pressure $>200 \mathrm{MPa}$. Sometimes results were good, sometimes cracks and delaminations occur [3]. Therefore, for the diffusion bonding of piezoelectric ceramics, the temperatures and the pressures must be applied as small as possible. This became possible when we used custom built thermosonic bonding equipment. Introduction of $15 \mathrm{kHz}$ vibrations into the bonding process allowed reducing temperature and pressure $\left(230{ }^{\circ} \mathrm{C}, 60 \mathrm{MPa}\right)$. Excellent results were achieved. It is necessary to emphasize, that reliable bonding happens only when a number of conditions are met in an optimized parameter window. The best combination of parameters depends on a surface treatment of bonded metals, pressure, temperature and ultrasonic power. "Trial and error" method must be used, as no modelling can lead to satisfactory results [45].

Temperature compensated piezoelectric transducer assembly for operation up to $350^{\circ} \mathrm{C}$ is diffusion bonded [46]. It comprises a lithium niobate piezoelectric element which is mounted on a metal base by means of a structured copper interlayer. The structured copper is a bundle of paralled filamentary strands of copper closely packed together (density $\sim 90 \%$ ). This bundle easily accomodates different thermal expansions of the assembly.

Diffusion bonding of gold-to-gold may be made by wetting the bonding surfaces with mercury and clamping the wetted surfaces together using a moderate pressure, for example, at the temperature of $100^{\circ} \mathrm{C}$ for a period of 22 to 30 days [47]. The bond tensile strength exceeds the yield point of gold.

For the possibilities of ultrasonic welding Morgan Electro Ceramics [48] produces piezoelements with the silver electrodes, polished to the surface flatness within 5 light waves, the surface finish within $0.3 \mu \mathrm{m}$.

1-3 conectivity composite material made of lithium niobate and cement for ultrasonic condition monitoring at elevated temperatures was bonded permanently to the test object with the same cement $\mathrm{Al}_{2} \mathrm{O}_{3}$ [15]. Unfortunately, after reaching $456^{\circ} \mathrm{C}$ and cooling, the composite transducer disbonded from the metal test block. However, the composite material itself was still intact and had survived. Further investigations are necessary to determine at what stage the material disbonds from the test block and whether this can be prevented. The same $\mathrm{Al}_{2} \mathrm{O}_{3}$ cement was used for bonding of $\mathrm{LiNbO}_{3}$ crystal to the Ti block and operated up to $600^{\circ} \mathrm{C}$ in the experiments with liquid Sn [39].

Epoxy as a bonding material can approach the high heat resistance of phenolics, in some cases up to $300^{\circ} \mathrm{C}$, without brittleness. This capability has been most fittingly used in an advanced space technology [49]. The high temperature epoxy (up to $300^{\circ} \mathrm{C}$ ) was used to bond $\mathrm{PbNb}_{2} \mathrm{O}_{6}$ piezoelectric material and a backing material [18]. New commercially available inorganic silver epoxy Aremco-Bond ${ }^{\mathrm{TM}} 597$ is silver filled with one part paste and is intended to use up to $927^{\circ} \mathrm{C}$. It is thermally and electrically conductive; its volume resistivity is 0.0002 $\mathrm{Ohms} / \mathrm{cm}$ [50]. This technology is used for the development of high temperature piezoelectric wafer sensors, based on ALN and $\mathrm{GaPO}_{4}$. They can function in a harsh environment, e.g. for aircraft jet engine and SpaceShuttle diagnostics, space reentry vehicle thermal protection systems, etc. [51].

As there is no good solution for a high temperature ultrasonic couplant, sol-gel [23-28, 52] and chemical vapor deposition (CVD) [20-22] technologies were developed in order to avoid coupling problems. It is necessary to emphasize that these technologies are being developed newly and are far from a final solution. Until now experiments are quite limited and there is no information about the adherence quality, thermal expansion coefficients, influence of the thermal shocks, etc. It is known only that CVD AIN films disbonded from $\mathrm{Ti}$ substrate upon reheating [22] and that stainless steel for this purpose is not suitable.

Smart material/actuator needs in extreme environments in space are analyzed in articles [4, 5]. Future mission in Solar System will require new technology. In addition to the extreme temperatures the technology may have to withstand high radiation and corrosive environments. Motors for mobility platforms, deployment devices, actuators for sampling tools, composite manipulators, ultrasonic drills are required. They are based on high temperature piezoceramics technology.

\section{Analysis of design of ultrasonic transducers for operation at high temperatures}

Conventional ultrasonic transducers will tolerate temperatures up to approximately $50^{\circ} \mathrm{C}$. At higher temperatures they will eventually suffer permanent damage due to internal disbonding caused by a thermal expansion. If the medium being tested is hotter than $50^{\circ} \mathrm{C}$ then high temperature transducers and special techniques should be 
employed [53]. Design of high temperature ultrasonic transducers depends on a piezoelectric element selected. PZT piezoceramics with the high thicknes mode coupling coefficient $k_{\mathrm{t}}=0.5$ are usually restricted to maximum temperatures of $\sim 150^{\circ} \mathrm{C}\left(T_{\mathrm{C}}=350^{\circ} \mathrm{C}\right)$. To overcome the thermal restrictions of PZT piezoceramics a waveguide (buffer rod) approach was developed and widely used. A big variety of waveguide design solutions is known.

An alternative approach is a direct contact transducer (with $\lambda / 2$ or thicker protector, delay line, immersion, etc.) in which only a high temperature piezoelement must be used, possessing a significantly lower coupling coefficient and requiring new solutions in the transducer design.

In a waveguide design a couple of problems must be solved: acoustic coupling between the ultrasonic transducer and the waveguide, transmission of the ultrasound through the waveguide, etc. The waveguide material has to meet several requirements [8] with respect to the desired acoustic, physical (thermal shock resistance, low heat coductivity, etc.) and chemical properties (errosion and corosion resistance). For high temperature applications, e.g. in flow measurements, the "transducer" end of a buffer waveguide is cooled down enough, so the sensor is not affected by the temperature of a hot end. Variuos measures are used to isolate it thermally without corrupting the signal. This relatively simple way to avoid having high temperatures at the transducer was already known to ultrasonic researches more than 50 years ago. The rod was usually made of solid metal, sometimes steel, occasionally tungsten. The diameter is typically $15-25 \mathrm{~mm}$. The external surface is threaded or grooved to break-up unwanted mode conversions. This solution works well at high frequencies, say 2-10 MHz, where the rod radius was $>3 \lambda, \lambda$ being the ultrasound wavelength in the rod [30]. In low frequency applications $(0.1-1 \mathrm{MHz})$ this requirement can not be fulfilled, and a "bundle waveguide technology" (BWT) was proposed. The wavequide consists of hundreds of wires enclosed inside a corrosian-resistant sleeve thus creating a rigid dispersion-free bundle [30]. The portion of BWT assembly within the insulated nozzle operates uncooled at the object temperature. The external part can be as long as necessary to convection-cool down to a temperature such as $100^{\circ} \mathrm{C}$, well within the range of ordinary piezoelectric materials and constructions. It is reported that BWT assembly worked well at temperatures $>200^{\circ} \mathrm{C}$, later at $340^{\circ} \mathrm{C}$ and can withstand $450^{\circ} \mathrm{C}$ during extreme conditions. Wires or single fibers in the bundle can be made of steel, alumina, etc. It has been shown [8] that even a large drop in a temperature will change the transmitted pulse only insignificantly. The ratio of the fibre diameter and the frequency should be chosen in accordance to the desired acoustic transmission behaviour. For example, at the $4 \mathrm{MHz}$ the maximum diameter for a steel fibre is $0.4 \mathrm{~mm}$. The bundle has to be covered by a shell; the active waveguide diameter is $10 \mathrm{~mm}$. For shear waves, obliquely incident, instead of using many thin wires one thin plate was proposed. The plate has certain topological features for generating reference echoes or for measuring temperatures at corresponding points. It resembles a small "hockey stick" at its abbreviation is OKS. OKS waveguides are clamp-on, and coupling is provided by the soft metal foil, which is thick enough.
An integrated ultrasonic sensor with an acoustic waveguide has been developed to overcome the thermal limitations of ultrasonic transducers. This sensor can be presently applied at maximum temperatures up to $600^{\circ} \mathrm{C}$, and an extension of the temperature can be expected [40]. The acoustic wavequide is fabricated of a stainless steel foil with the thickness of $0.1 \mathrm{~mm}$ and the length of $200 \mathrm{~mm}$ which is wrapped axially around a capillary tube. For measurements of the Doppler shift in the signal a dispersionless propagation of the ultrasonic wave of the frequency $f$ inside the wavequide has to be required resulting in a restriction of the thickness $d$ of the wavequide of the thickness $d$ of the waveguide: $d \times f / c<0.1$ [54]. The sound velocity $c$ for longitudinal waves propagating in steel is about $5000 \mathrm{~m} / \mathrm{s}$. Therefore, at 4 $\mathrm{MHz}$ the thickness $d$ has to be limited to a maximum of $0.125 \mathrm{~mm}$ to provide the mono-mode behaviour of the waveguide. The waveguide has an outer diameter of $7.5 \mathrm{~mm}$. The waveguide is closed at the front end by means of laser beam welding. The $4 \mathrm{MHz}$ piezoelement is welded directly on the rear end of the waveguide. The welding technology is not disclosed. This waveguide sensor is applied to ultrasound Doppler velocimetry of liquid metal flows.

Clad steel buffer rods consisting of a core and a cladding were doveloped for ultrasonic monitoring of industrial process. The core is made of low ultrasonic loss steel, and the stainless steel cladding fabricated by thermal spray techniques ensures proper ultrasonic guidance [55]. These rods ranging from tens of centimeters to $1 \mathrm{~m}$ long can function under temperature up to $960{ }^{\circ} \mathrm{C}$. The ultrasonic transducer end of the buffer rod is air cooled so that the high performance room temperature transducers can be used. It is reported, that a short buffer rod has a length of $131 \mathrm{~mm}$ and a probe end diameter of $7.8 \mathrm{~mm}$. This length is long enough such that the air cooling would not affect the temperature at the probing end of the clad rod, but it is short enough to have a small propagation losses and size. The air cooling pipes are installed, and the cooling keeps the temperature at the ultrasonic transducer end below $50^{\circ} \mathrm{C}$. The diameter of the transducer is 6.35 $\mathrm{mm}$. The signal-to-noise (SNR) is excellent. It is noted that the clad buffer rods also have superior performance in shear wave pulse echo measurements. For liquid metals, e.g. liquid aluminum at $967{ }^{\circ} \mathrm{C}$, a clad steel rod has a length of $1 \mathrm{~m}$. At $5 \mathrm{MHz} 50 \mathrm{~dB}$ SNR is reported.

Development of instrumentation and high temperature ultrasonic transducers has to be considered as a very difficult problem [8]. The waveguide concept enabled to apply these transducers in various fields in industry and scientific investigations: high temperature ultrasonic Doppler velocimetry, including flows of liquid metals; monitoring of polymer extrusion and thickness of metals, including liquid metals, at very high temperatures; measuring flows of hot gas at elevated pressures, as well as hot flows of various liquids, etc.

Design of a direct contact conventional ultrasonic transducer must be radically changed for operation at high temperatures. It depends on a piezoelectric element type as well as on a bonding method to the protector layer and backing. 
Commercially several high-temperature ultrasonic transducers are supplied by companies, such as Etalon [56], Panametrics [33], Ultran [57], SIGMA transducers [58], etc. All standard Panametrics high temperature transducers are designed with a duty cycle in mind. Although the delay line insulates the interior of the transducers, the recommended duty cycle for surface temperatures between $90^{\circ} \mathrm{C}$ and $425^{\circ} \mathrm{C}$ is no more than ten seconds of the contact with the hot surface (five seconds is recommended), followed by a minimum of minute of air cooling [33]. For design reasons there are no high temperature contact or immersion transducers in the standard product line. Most of SIGMA transducers can be fabricated to operate at higher temperatures than it is generally available in the market place at large. Selection of the proper materials other than epoxies and solders allows operation of these units up to $230^{\circ} \mathrm{C}$ continuously. Delay lines can prolong the operation a little.

The same situation is with the commercial transducers of other companies.

The internal design of commercial high temperature ultrasonic transducers is not disclosed. Ultran [57] high temperature direct contact transducer HTC is intended for $250^{\circ} \mathrm{C}$ continuous operation, is supplied with a special high temperature-resistant $2 \mathrm{~m}$ wire terminated into a standard BNC connector. The compression-held piezoelectric assembly in a ceramic chamber is patented. The frequencies are between 0.5 and $5 \mathrm{MHz}$, the active diameters 6.3 and $12.5 \mathrm{~mm}$. The transducer HTD is intended for $600^{\circ} \mathrm{C}$ continuous operation and is equiped with a fixed delay line. The transducers HTC and HTD are characterized by bandwidths $30 \div 50 \%$ and $40 \div 70 \%$ respectively $(-6 \mathrm{~dB})$, pulse widths $3 \div 6$ and $2 \div 4$ periods.

Hagisonic [59] high temperature transducers are single element contact transducers which are designed to operate up to $500^{\circ} \mathrm{C}$. Their application is detection of defects at high temperature, high temperature thickness and corrosion measurements. The main features are the following: super hard alumina inner tube and matching plates, built in a high temperature resistant coaxial cable, corrosion resistant stainless steel housing. It is not clear if they are intended for continuous operation up to $500^{\circ} \mathrm{C}$, or in duty a cycle mode. The pulse diagrams show that peak-to-peak voltage of the first reflection (near 10 decaying cycles) in $40 \mathrm{~mm}$ steel block with a gold couplant decreases nearly 10 times (from $1.7 \mathrm{~V}$ to $0.18 \mathrm{~V}$ ) at $500{ }^{\circ} \mathrm{C}$ as compared to the room temperature $25^{\circ} \mathrm{C}$. Endurance test under high temperature $500^{\circ} \mathrm{C}$ shows decrease of the signal in successive repetitions as well.

Imasonic [60] single element high temperature transducers are intended for permanent contact only at $130^{\circ} \mathrm{C}$.

Panametrics [53] emphasizes that at $>50^{\circ} \mathrm{C}$ high temperature transducers and special test techniques should be employed. Conventional ultrasonic transducers are recommended only up to approximately $50^{\circ} \mathrm{C}$, at higher temperatures they will eventually suffer permanent damage due to internal disbonding caused by thermal expansion. High temperature transducers are capable to operate up to approximately $500^{\circ} \mathrm{C}$, but in a duty cycle mode. High temperature transducers fall into two categories: dual element and delay line. In both cases the delay line material which is internal in the case of duals serves as thermal insulation between the active transducer element and the hot test surface. For design reasons, there are no high temperature contact or immersion transducers in the standard product line. The D790 (dual) series transducers can be used on surfaces as hot as $500^{\circ} \mathrm{C}$. In challenging applications the delay line transducers can be used in contact with surfaces as hot as $480^{\circ} \mathrm{C}$. These transducers are used with specialized high temperature couplants, which must be used quickly since they will tend to dry out or solidify and will no longer transmit ultrasonic energy.

Delay line high temperature ultrasonic transducers were developed in Federal Institute for Material Research and Testing (BAM, Germany) which could withstand continuous heating up to $250^{\circ} \mathrm{C}$, above this value the probe must be cooled off after measurement. The delay line material of the probes is a special ceramic and it can be used up to $800^{\circ} \mathrm{C}$ [61]. New developments are carried out in transducers for continuous scanning up to $400^{\circ} \mathrm{C}$ and in phased arrays [34]. Novel wedge materials like polyamides can withstand extremely high temperatures and still have good ultrasonic properties. Different combinations of crystals backings and matching layers must be tested to benefit from the maximum sensitivity and the signal to noise ratio. Passive cooling is achieved by new designs of the transducer housings, while the other option is an active cooling system. An independent system can be built into the probes which provide the necessary cooling. It is emphasized that the couplants which can be used above $350^{\circ} \mathrm{C}$ still are a problem and improvements in this area would be welcome [34].

Optel [62] offers high temperature transducers with a water cooled delay line made from stainless steel or ceramics.

High temperature immersion type ultrasonic imaging probes are presented in [18]. These probes consist of piezoelectric transducers and short buffer rods and operate in a pulse-echo mode. The operating temperature is up to $215^{\circ} \mathrm{C}$ and there is no need for a cooling system. For imaging purposes one end of the clad buffer rod is attached to a piezoelectric transducer and another end is machined into a semi-spherical concave shape that provides the focus. The operating frequency is $5 \mathrm{MHz}$. The piezoelectric material is a lead niobate compound $\left(\mathrm{PbNb}_{2} \mathrm{O}_{6}\right)$ that has the Curie temperature of about $540^{\circ} \mathrm{C}$. This temperature warrants the use of this transducer up to $300^{\circ} \mathrm{C}$. This piezoelectric ceramic material has a good thermal shock resistance. The backing is made of a solid polyamide and has acceptable ultrasonic damping. The $\mathrm{PbNb}_{2} \mathrm{O}_{6}$ piezomaterial is bonded to the backing through a high temperature epoxy, while to the rod with a thin layer of silicone oil as couplant in between.

The solid backing makes the probe broadband but ultrasonic echoes in it become the major spurious signals in the pulse- echo mode. In order to overcome such a drawback, the clad buffer rod consisting of a steel core and a stainless steel cladding is used as a delay line. It was shown that in a non-clad buffer rod may propagate many different modes, while in the clad buffer rod propagate much less modes. It is reported, that silicone oil may be 
used up to $250^{\circ} \mathrm{C}$ with little evaporation provided a proper sealing was achieved. Ultrasonic images obtained by mechanical scanning and plotting the time delay of the echo and the echo amplitude are presented.

Several commercially available high temperature ultrasonic transducers attached to non-clad buffer rods were also investigated. IIICL (Tokyo, Japan) $\mathrm{LiNbO}_{3}$ transducer was bonded to the $20 \mathrm{~mm}$ long $10 \mathrm{~mm}$ diameter titanium non-clad buffer rod via a brazing technique. Although this high temperature ultrasonic transducer with titanium buffer rod could function up to $450^{\circ} \mathrm{C}$, the measurements were stopped at $205^{\circ} \mathrm{C}$. Experiment failed as the signals in the reflection mode were good only till $140^{\circ} \mathrm{C}$, in some measurement modes only till $50^{\circ} \mathrm{C}$. The couplant made by the brazing technique and a poor propagation of ultrasonic waves in the non-clad titanium rod caused a low signal-to-noise ratio in this probe, while the brazing technology is not discussed. Probably the probes could be damaged. Similar observations were obtained when other commercially available probes were evaluated. The authors did not disclose the manufacturers.

Piezoelectric elements in delay line transducers may be at a lower temperature than the test object if they are intended to use in a duty cycle mode, e.g. [53], or approximately at the same high temperature in a continuous operation mode [18].

In high temperature contact or immersion transducers with thin or thicker protectors the piezoelements are always at the same high temperature, thus they must be characterized by a high Curie temperature. However, information about these transducers is quite limited.

A compact and stable ultrasonic transducer for undersodium scanner was developed for Fast Breeder Test Reactor (FBTR), where liquid sodium is used as the coolant [37]. In the first versions of the transducer a high temperature grease was used as a couplant within the transducer as an acoustic bond between the piezoelectric crystal and the transducer face. It had a limited life around few hundred hours at the operating temperature of $200^{\circ} \mathrm{C}$. In the second version the crystal was soldered to the transducer face with a high temperature solder (the melting point $220^{\circ} \mathrm{C}$ ). The welded construction provided the helium-leak-tight integrity. The transducers were tested in silicone oil at the temperature of $200^{\circ} \mathrm{C}$ and were found to perform well. The transducers have only a thin membrane and the damping body is absent, thus the piezoelement is damped only by silicone oil or liquid sodium. Later the transducer was developed for continuous immersion in sodium up to a temperature of $250^{\circ} \mathrm{C}$ [63].

A comprehensive study of high temperature ultrasonic transducers and the development of a prototype ultrasonic probe is discribed in [16]. It is emphasized, that at temperatures $>200^{\circ} \mathrm{C}$ ultrasonic testing is based usually on electromagnetically generated ultrasound using EMAT transducers. No new way of developing piezoelectric transducers was found in literature. The developed prototype ultrasonic probe had the Inconel-600 $\lambda / 2$ membrane $(\sim 0.6 \mathrm{~mm})$, which is closing the front of the austenite housing and matching the acoustic impedance. No buckling of the membrane greater than $10 \mu \mathrm{m}$ was observed, neither at a room temperature, nor at $800^{\circ} \mathrm{C}$ up to 2.5 -fold of the working pressure. The $\mathrm{LiNbO}_{3}$ single crystal as well as the LNN ceramics transducer of the $20 \mathrm{~mm}$ diameter was coupled to the membrane by means of the glass solder NaPoLi. The damping body of the glass coated porous ceramic with the trade name "Kager 9900" was soldered to the crystal with the same glass solder. The damping body had concentric cuts at the back side in order to improve absorption. All probe parts were pressed together with a package of serially chained cup springs of Inconnel 600. Alternatively, the ceramic springs demonstrated the high performance and stability of the material. The spring diameter was $46 \mathrm{~mm}$ and the high $23 \mathrm{~mm}$. During 257 hours 8 temperature cycles up to $800^{\circ} \mathrm{C}$ have been performed with a spring tension of $50 \mathrm{~N}$ and a spring deflection of $3.5 \mathrm{~mm}$. The transducer crystal was capacitively coupled to the electric circuitry by means of the $50 \mu \mathrm{m}$ austenitic steel foil with the nickel wire welded to it. The ground connection was also capacitive. The capacitive connection means that the glass solder is not conductive. The transducer housing was laser welded and the high temperature metallic/mineral cable was used. A backwall echo from a $20 \mathrm{~mm}$ thick specimen shows that the ultrasonic pulse consists of $\sim 6$ cycles. High temperature experiments revealed that the glass solder approach has some problems and the coupling problem is far from the final solution.

The first version of the 1-3 connectivity composite transducer made of $\mathrm{LiNbO}_{3}$ and high temperature alumina adhesive cement was in an experimental stage and without any housing [15]. Four designs of composite were tested: "fat pillar", "thin pillar", "fat pillar" diced at $45^{\circ}$ and platelet. No electromechanical enhancement was found as a result of making a composite of lithium niobate. However, platelet or pillar designs operating in a thickness mode could both be used to obtain better mechanical and thermal resistance properties than the monolithic lithium niobate. The electrodes were thick film gold tracks on a ceramic alumina "array plate". The electrodes were connected either in groups or used separately. Using long wires, the array could be excited remotely. This is important for the future developments in array applications. In the experiments presented all transducer pillars were excited simultaneously. Unfortunaly, the bonding problem to the test block was not solved yet. More results concerning a piezoelectric linear array structure designed to operate at temperatures up to $400^{\circ} \mathrm{C}$ for nondestructive testing of steel components of a hot industrial plant a provided in [64]. These arrays are used in pairs: the transmitter is a phased array producing a variable angle steered beam, and the second array is used as a receiver. The prototype devices have 64 elements. The results show the accuracy better than $1 \mathrm{~mm}$ in finding the location of crack tips. Two cuts of litium niobate $\left(\mathrm{Y} / 36^{\circ}\right.$ rotated and $\mathrm{Z}$-cut) and bismuth titanate were investigated. Good results were obtained for $\mathrm{Y} / 36^{\circ}$ cut; the coupling factor $k_{\mathrm{t}}$ values were correspondingly $0.49,0.17$ and 0.12 . For high temperature tests array connection pins were clipped on with the wires and fixed with high temperature cement. As a final solution a more permanent and robust method of attachment for use at high temperatures was proposed. It could be a spot welding of the connection pins to the 
mineral insulated leads and later to the head resistant coaxial cables. It is not clear if this method was realized in practice. A suitable method of array coupling to the test block is vitally important for high temperature operation. It was found that high temperature commercial couplants did not survive for long periods. The tested couplants burned or dried out while being heated to $400^{\circ} \mathrm{C}$ over several hours, although they were rated for from $400^{\circ} \mathrm{C}$ to $500^{\circ} \mathrm{C}$. Some success was recorded only up to $250^{\circ} \mathrm{C}$. Metal alloy brazes (e.g., gold-indium, the melting point $637^{\circ} \mathrm{C}$ ) have been shown to transmit sound well, but braze bonds would be difficult to prepare. The authors found that the most practical couplant to reach a test block temperature of $400^{\circ} \mathrm{C}$ was Cotronics 989 alumina-based cement. In the first experiments they had disbonding problems [15]. After the technology improvement in the longest test the cement coupled array survived for 3 weeks at high temperature without deterioration in its performance.

For manufacturing of miniature high temperature ultrasonic transducers the lead-free thick bismuth titanate films have been successfully deposited on steel substrates of different shapes by the sol-gel spray technique [65, 66]. A short description of the film fabrication process is presented. The bismuth titanate (BIT) $80 \mu \mathrm{m}$ powders are dispersed into BIT solution by ball milling method to achieve the gel. The final dimension of the BIT is estimated to be less than $1 \mu \mathrm{m}$. These films are called BIT/BIT. The center frequencies on steel samples ranged from 5 to $30 \mathrm{MHz}$, their bandwidth was broad. For example, the $10 \mathrm{MHz}$ ultrasonic transducer had $7 \mathrm{MHz}$ bandwidth at the $-6 \mathrm{~dB}$ level. The signals generated and received by these ultrasonic transducers had a signal to noise ratio $25 \mathrm{~dB}$ at $200^{\circ} \mathrm{C}$ in a pulse/echo mode. This transducer can be as small as $1 \mathrm{~mm}$ in the diameter. Similar $\mathrm{BIT} / \mathrm{PZT}$ films operated up to more than $400^{\circ} \mathrm{C}$ [67]. A top electrode was formed using silver paste thus replacing the vacuum sputtering. The electrodes performed well at high temperatures. The frequency responses of echoes at $24^{\circ} \mathrm{C}$ and $200^{\circ} \mathrm{C}$ in a steel substrate are presented. The signals practically are identical. This sample has been thermally cycled many times in a furnace, and no deterioration of the film quality has been observed. By comparing the data it was found [67], that the strength of the signal generated by the BIT/BIT thick film ultrasonic transducer on this flat steel plate was $20 \mathrm{~dB}$ weaker than by the BIT/PZT thick film.

Techniques for generation of ultrasound for extended periods at high temperatures are reviewed in [68]. Some transducer materials and various types of adhesive bonds were considered. Measurements of insertion losses, the transducer coupling factor and the capacitance indicated that the most successful transducer-bond combinations were PZT-5A with a solder bond for use up to $250^{\circ} \mathrm{C}$, and lithium niobate with either ceramic or gold-indium bond for use up to $400^{\circ} \mathrm{C}$. These three combinations all proved relatively stable for periods in excess of 400 days at high temperatures.

An ultrasonic sensor was developed, manufactured and tested for high temperature materials processing [21]. It is capable of emitting and receiving ultrasonic energy at temperatures exceeding $900^{\circ} \mathrm{C}$ and pressures above $150 \mathrm{MPa}$. The sensor demonstrated the capability of measuring workpiece deformation during hot isostatic pressing. Details of the sensor design, performance and coupling of the ultrasound to the workpiece are described. It is emphasized, that commercially available ultrasonic transducers are limited because of transducer materials. Electromagnetic acoustic transducer (EMAT) requires that the target material would be electrically conductive and they are very inefficient sources of ultrasonic energy. The piezoelectric material in this new transducer is aluminum nitride (AIN) film, deposited on a substrate (tungsten carbide or graphite), serving as a damping body, which is conductive and at the same time serves as a "hot" electrode. A nickel-based superalloy was selected as the housing material because of its high temperature stability and ease of machining characteristics. The rhenium spring and Inconel push rod keep the substrate pushed against the front of the precisely machined housing. Since the thermal expansion of the housing is matched by the expansion of the push rod, the spring force is constant regardless of the temperature. Achieving of electrical connections to the AlN film ("ground" electrode) required considerable research and development efforts. The film was plated with platinum, and the platinum-covered surface was mechanically forced against the inside of the sensor housing at the narrow edges, the rest front face had a hole. The sensor cable was metallic. The inner wire was welded to the push rod fitted into a hole in the substrate. To produce an ultrasonic energy, a several hundreds volts were applied across the AlN film. Two approaches were taken to produce an efficient ultrasonic coupling between the sensor and the workpiece. The first approach used the gas at elevated pressures as the coupling medium, while the second used metals or glasses as liquid couplants that melted at $700-800^{\circ} \mathrm{C}$. Preliminary tests conducted at low temperatures $\left(<100^{\circ} \mathrm{C}\right)$ over a pressure range from atmosphere to $20 \mathrm{MPa}$ demonstrated that ultrasound in the frequency range $15-25 \mathrm{MHz}$ may propagate through the gas (e.g. Ar) at pressures above $20 \mathrm{MPa}$. Propagation distances of $100 \mathrm{~mm}$ were easily achieved. Test results show that the peak-to-peak signal amplitude is varying only $\pm 25 \%$ in the temperature range $20-800^{\circ} \mathrm{C}$, but the signal to noise ratio is very poor. Liquid coupling results are not provided.

We have developed some prototype ultrasonic sensors for operation in a heavy liquid metal. The sensors are high temperature, $\gamma$ and neutron radiation resistant, they can operate continuously in a liquid $\mathrm{Pb} / \mathrm{Bi}$ alloy up to a temperature of $450^{\circ} \mathrm{C}$ [1-3]. Taking into account the design requirements it was necessary to solve the following main problems: to select suitable piezoelectric materials, to optimize the sensor design, ensure reliable acoustic coupling of a piezoelement to the protector (and the backing) in the temperature range $150-450^{\circ} \mathrm{C}$, to get a durable and stable long-term acoustic coupling of an ultrasonic sensor to the liquid metal. Most of these requirements to particular elements contradict each other and therefore some trade-off between them must be found. Some sensor types were investigated: transducers with a buffer rod (with a measurement cell), with a thin $(\sim \lambda / 2)$ or 
thick $(>>\lambda)$ metallic membrane, with or without damping body. Different transducer types were optimal for solution of different tasks: ultrasound velocity measurements in a liquid $\mathrm{Pb} / \mathrm{Bi}$ in a wide temperature interval, evaluation of signal losses at long distances, irradiation tests, longlasting wetting experiments, transducer design optimization, etc. Five piezoelectric materials were investigated, including irradiation influence on a transducer operation: PZT, lithium niobate, bismuth titanate, galium orthophosphate, aluminium nitride. The bismuth titanate transducers demonstrated best high temperature performance and radiation resistance. Dry coupling with a high pressure was used in buffer rod transducers up to $450^{\circ} \mathrm{C}$. In transducers with a thin or thick protector high temperature soldering $\left(<300^{\circ} \mathrm{C}\right)$ or finally gold-to-gold diffusion bonding method was applied $\left(\div 450^{\circ} \mathrm{C}\right)$. However, at higher temperatures soldering and diffusion bonding of piezoelements becomes problematic due to the local stresses and the possible cracks in piezoceramics leading to the separation of a thin layer of ceramics under the whole surface of the piezoelectric element together with an electrode. Thermosonic approach solved these problems and acoustically good bonds are achieved. The stainless steel housing is laser welded, the polished front face of the thick membrane is DLC coated for improvement of acoustic coupling to the liquid metal. A high temperature cable is laser welded as well. The inner "hot" connections are made by means of a narrow strip of $20 \mu \mathrm{m}$ gold foil connected by a diffusion bonding to the gold electrode of the piezoelement and pressed to the gold coated tip of the cable.

In high temperature ultrasonic transducers mineral insulated signal transmission cables must be used, e.g. THERMOCOAX [69]. Thanks to their exceptional properties, these cables can be used in most aggressive media such as corrosive liquids or gases, under high pressure, vacuum, vibrations, in nuclear industry. They resist to a temperature up to $1200^{\circ} \mathrm{C}$ and can easily be welded or brazed onto any piece. They also can carry relatively high currents as well as very low signals at high frequencies. The outer diameter of the cables varies from $(1 \pm 0.03) \mathrm{mm}$ to $(6 \pm 0.05) \mathrm{mm}$. The sheath may be copper plated $304 \mathrm{~L}$ stainless steel, stainless steel, ironcoper-stainless steel, etc. The core is made of copper, stainless steel, zirconium copper coated, etc. The insulant is a mineral powder with a low dielectric constancy, magnesia $>94 \%$, alumina $99.6 \%$. The characteristic impedance is $(50 \pm 3)$ ohms. The line capacity depends on the insulant and the diameter of the cable and may be $(110-350) \mathrm{pF} / \mathrm{m}$. The line resistance is $(0.13-16) \mathrm{Ohms} / \mathrm{m}$. Attenuation in the cable is very low- only $0.5 \mathrm{~dB} / \mathrm{m}$ up to $20 \mathrm{GHz}$ (for $\varnothing 3 \mathrm{~mm}$ cable).

Diffusion bonding was used in making piezoelectric actuators [70]. Fabrication of the actuators involves the stacking and diffusion bonding of multiple thin piezoelectric layers coated with silver electrodes. The stacked piezoelectric layers are placed in a press for the diffusion bonding process. The stack is pressed and heated at "a specified curing temperature and pressure for a specified curing time" [70]. The pressure, the temperature and the time depend on the piezoelectric material selected. No technological details are disclosed.

The difficulties in high temperature packaging lie not only in finding materials that can survive at temperatures exceeding $300^{\circ} \mathrm{C}$, but in finding compatibility between materials and assembly techniques also [71]. At high temperatures incompatibilities between materials become exaggerated. Factors such as a thermal conductivity, expansion coefficients, oxidation and diffusion become critical as operating temperatures increase and play influential roles in the selection of packaging materials. Nickel was chosen as the circuit conductor because it possesses the best balance of properties for high temperature electrical performance. The conductivity of nickel is not as high as desired, but it is adequate. Plus, it has the best resistance to oxidation. Reliable interconnection at high temperatures is very important, and wire bonding is the prefered method. The gold bonding is most suitable, so nickel conductor in the area of bond must be gold plated to avoid diffusion between dissimilar metals at high temperatures.

Modern interconnection methods developed for milimeter range wave high power Gunn devices [72] may be useful in high temperature ultrasonic transducer design. They are packed with a metal block for efficient heatsinking using a thermosonic bonding technique for a reliable assembly. The solid gold-to-gold diffusion can occur at a relatively safe temperature $\left(<200^{\circ} \mathrm{C}\right)$, but the bond survives and improves at higher temperatures.

\section{Conclusions}

After the analysis of the existing solutions of high temperature waveguide and direct contact ultrasonic transducers, including the achievements of the Kaunas University of Technology Ultrasound Institute, the following conclusions can be made.

1. For operation at high temperature the most suitable are piezoelectric elements made of the following materials: bismuth titanate $\mathrm{Bi}_{4} \mathrm{Ti}_{3} \mathrm{O}_{12}$ (BIT); modified BIT; lead metaniobate; BIT/PZT film (sol-gel technology).

2. For bonding of the piezoelectric elements to the protector the thermosonic gold-to-gold or silverto-silver diffusion bonding method may be proposed. This process must be still optimized. In the BIT/PZT film approach the bonding procedure is avoided at all.

3. Design of high temperature ultrasonic transducers depends on the piezoelement and the bonding method selected. The transducer may be direct contact type, placed into Inconel-600 or stainless steel housing, with a thicker protector, thus the backing may not be necessary (protector damps the piezoelement). Electrical connection with the transducer is provided by a high temperature metallic cable, which is by a laser welded to the housing.

4. Electrical connection of the piezoelement to the cable and other inner connections may be provided by means of the soldered (e.g. solders 
Au88Ge12, Au82In18) or with gold-to-gold bonded or pressed gold wires or foil strips.

\section{References}

1. Kazys, R. Voleisis A., Sliteris R., Voleisiene B., Abderrahim H. A., Kupschus P. Development of ultrasonic transducers for ranging and imaging in heavy liquid metal. In: Proc. IEEE Sensors. 2004, Vienna, Austria. October 24-27, 2004. P. 646-649.

2. Kazys R., Voleisis A., Sliteris R., Mazeika L., Van Nieuwenhove R., Kupschus P. and Abderrahim H. A. High temperature ultrasonic transducers for imaging and measurements in a liquid $\mathrm{Pb} / \mathrm{Bi}$ eutectic alloy. IEEE Transactions on Ultrasonics, Ferroelectrics and Frequency Control. 2005. Vol. 52.No. 4. P. 525-537.

3. Kazys R., Voleisis A., Sliteris R., Voleisiene B., Mazeika L., Kupschus P., Abderrahim H. A. Development of ultrasonic sensors for operation in a heavy liquid metal. IEEE Sensors Journal. 2006. Vol. 6. No.5. P. 1134-1143.

4. Sherrit S., Bao X., Bar-Cohen Y., and Chang Z. Resonance analysis of high temperature piezoelectric materials for actuation and sensing. Proc. SPIE smart Structure Conference, San Diego, CA., March 14-18, 2004. SPIE Vol. 5387. 10P.

5. Sherrit S. Smart material/actuator needs in extreme environments in space. Proc. SPIE Smart Structure Conference, San Diego, CA., March 6-10, 2005. SPIE Vol. 5761. 12P.

6. Lach M., Platte M., Ries A. Piezoelectric materials for ultrasonic probes. NDTnet, September 1996. Vol. 1. No. 09.

7. Acoustic properties of longitudinal piezoelectrics. Onda Corporation, Sunnyvale, CA.

www.bmtp.akh-wiev.ac.at/people/kollch1/kolllink.html.

8. High temperature ultrasonic velocimetry (HITUV). Research project supported by the European Commission within the Fifth Framework Programme.

http://www.fz-rossendorf.de/FWS/FWSH?Sven/hituv.html

9. Ferroperm-high quality piezoelectric ceramic components for the electronics industry. Material data.

http://www.ferroperm-piezo.com/Material_Data.html.

10. Pz46. Bismuth Titanate for operation above $500^{\circ} \mathrm{C}$. http://www.ferroperm-piezo.com

11. Seacor Piezo Ceramics-Material Properties. www.seacorpiezo.com/mat prop/-9K

12. Ultra high-temperature piezoelectric ceramic with extreme piezoelectric stability.

http://www.piezotechnologies.com/k15.htm

13. Keramos Materials Specifications. http://piezotechology.com/materialssheet.htm

14. Innovation in Europe: Research and Results. "Non-destructive testing at $800^{\circ} \mathrm{C}$ ".

http://europa.eu.int/comm/research/success/en/mat/0041e.html

15. Shepherd G., Cochran A., Kirk K. J., McNab A. 1-3 connectivity composite material made from lithium niobate and cement for ultrasonic condition monitoring at elevated temperatures. Ultrasonic NDE/NDT. Version 2, 2-Jul-01. 12.P.

16. Mrasek H., Gohlke D., Matthies K., Neumann E. High temperature ultrasonic transducers. NDTnet, September 1996. Vol. 1. No. 09. 15P.

17. Soejima J., Sato K. and Nagata K. Preparation and characteristics of ultrasonic transducers for high temperature using $\mathrm{PbNb}_{2} \mathrm{O}_{6}$. Jpn. J. Appl. Phys. 2000. Vol. 36. P. 3083-3085.

18. Rehman A.U., Jen C.K. and Ihara I. High temperature immersion type ultrasonic imaging probes. Review of Progress in Quantitative Nondestructive Evaluation. Vol. 20, ed by D. O. Thompson and D. E. Chimenti. American Institute of Physics. 2001. P. 845-852.

19. Worsch P. M., Krempl P. W., Kreiter F., Thanner H. and Wallnofer W. $\mathrm{GaPO}_{4}$ crystals for sensor applications. AVL List $\mathrm{GmbH}$, Austria.

www.ewh.ieee.org/tc/sensors/Sensors2002/advprog/47.htm
20. High temperature ultrasonic transducer and detection system. US. Patent No. 5886456. 1999.

21. Stubbs D. A. and Dutton R. E. An ultrasonic sensor for hightemperature materials processing. JOM. 1996. Vol. 48 (9). P. 29-31.

22. Sebastian J. Elevated temperature sensors for on-line critical equipment health monitoring. University of Dayton Research Institute, Department of Energy Review Meeting, University coal Research Program, June 9, 2004.

23. Development of high temperature ultrasonic transducers (HTUT's) for industrial materials process monitoring. http://www.physics.quensu.ca/wwwhome/assg/joanna.html

24. Development of high temperature ultrasonic transducers (HTUT's). http://data.ctn-rct.nrccnrc.gc.ca/cnt/CTNServlet?calyHandler=OfferingPageHandler

25. Kobayashi M., Olding T. R., Sayer M. and Jen C. K. Piezoelectric thick film ultrasonic transducers fabricated by a sol-gel spray technique. Ultrasonics. October 2002. Vol. 39. Issue 10. P. 675-680.

26. Kobayashi M., Jen C. K., Corbeil C., Ono Y., Hebert H. and Derdouri A. High temperature ultrasonic transducers for monitoring of micro- molding. In: IEEE Ultrasonic Symposium, Honolulu, Hawaii, Oct. 5-8, 2003. 6P.

27. Kobayashi M. and Jen C. K. Piezoelectric thick bismuth titanate/lead zirconate titanate composite film transducers for smart NDT of metals. Smart Materials and Structures. 2004. Vol. 13. P. 951-956.

28. Beeby S. P., Torah R. N., Grabham N., Tudor M. J., White N. M. Thick-film piezoelectric materials for high temperature applications. Ferroelectrics. 2004. Vol. 313. P. 63-69.

29. McNab A., Kirk K. J. and Cochran A. Ultrasonic transducers for high temperature applications. IEE Proceedings-Science, Measurement and Technology. September 1998. Vol. 145, Issue 5. P. 229-236.

30. Lynnworth L. High-temperature flow measurement. Panametrics, Inc.

http://www.sensorsmag.com/articles/1099/36/main.shtml

31. AlN sensors. HCF 2000 Annual Report, Section3.2, 2000. http://www.hcf.utcdayton.com/2000report/pages/sec32.htm

32. Method of using a high temperature ultrasonic couplant material. US Patent 4738737. 1988.

33. High temperature ultrasonic testing. Panametrics-NDT. http://www.panametrics-ndt.com/ndt/ndt_technology/hi-temp.html

34. Huynen H. H., Dijkstra F. H., Bouma T. Advances in ultrasonic transducer development. In: Proc. $15^{\text {th }}$ WCNDT, Roma. 2000. 4P.

35. Sonotech Sono 1100 film. What's new in NDT ultrasound couplants. http://www.newcoinc.com/products

36. Bonding material and method. US Patent 4069083. 1978.

37. Asokane C., Elumalai G., Swaminathan K. Compact and stable ultrasonic transducers for under-sodium scanner. http://www.igcar.ernet.in/lis/n138/ta2.htm

38. Hosking F. M., Stephens J. J. and Rejent J. A. Intermediate temperature joining of dissimilar metals. Welding Research supplement. April 1999. P.127-136.

39. Takagi K., Ohtaka M., Natsui H., Arai T. and Yoda S. Experimental study of thermocapillary flow in the half-zone liquid bridge of low prandtl number fliud. iss.sfo.jaxa.jp/utiliz/surp/ar/marangoni/00/2_2.html

40. Eckert S., Gerbeth G., Melnikov V. I., Lefhalm C.H., Knebel J. Application of ultrasound doppler velocimetry to flows of hot metallic melts. Third Intern. Symp. On Ultrasonic Doppler Methods for Fluid Mechanics and Fliud Engineering EPFL. Lausanne, Switzerland, September 9-11, 2002. P. 77-82.

41. Bonded ultrasonic transducer and method for making. US Patent 5465897. 1995.

42. Bonding bulk PZT to Silicon/Other.

http://mai.mems-echange.org/pipermail/mems-talk/1998.html

43. Yerganian S. S. Ceramic element bonding for piezoelectric motors. Honeywel. Topical report. KCP-613-6342. 2000. P. 1-23.

44. Technology opportunity. Indium cold welding. 
http://technology.grc.nasa.gov/tops/TOP3.00040.pdf

45. Han L., Zhong J. Nonlinear behaviors of transducer dynamics for thermosonic bonding. In: Proceeding of the IEEE-CPMT HDP06 Conference on High Density Microsystem Design and Packaging and Component Failure Analysis, Shanghai, June 27-30, 2006. 8P.

46. Temperature compensated piezoelectric transducer essembly. US Patent 4825117, 1989.

47. Diffusion bonding of gold to gold. US Patent 3923231. 1975.

48. Morgan ElectroCeramics. Piezoelectric materials. http://www.morganadvancedceramics.com/MECenquiry/contact.htm

49. General information \& instructions for epoxies. http://www.discovery.org.hk/epoxy.htm

50. AREMKO. Electrically\&Thermally Conductive Materials. Technical Bulletin A8. Product highlights Pyro-Duct ${ }^{\mathrm{TM}}$ 597-A. http://www.aremco.com/a8.html

51. Kendall J., Giurgiutiu V., Xu B., Laskis J. Piezoelectric active structural diagnostic method development for structural health monitoring in high temperature aggressive environments. $17^{\text {th }}$ AeroMat Conference \&Exposition, May 15-18, 2006. Seattle, Washington. http://asm.confex.com/asm/aero06/techprogram/paper_13535.htm

52. Ono Y., Kobayashi M., Moisan J. F. and Cheng-Kuei J. High temperature and broad band immersion ultrasonic probes. IEEE Sensors Journal. June 2006. Vol. 6. No. 3. P. 580-587.

53. Panametrics NDT. High temperature ultrasonic testing. http://www.panametrics-ndt.com/ndt technology/hi-temp.html

54. Eckert S., Gerbeth G. and Melnikov V. I. Ultrasonic velocity measurements in liquid metals using acoustic wave guides. P. 24-30. http://www.fr-rossendorf.de/FWS/publicat/JB02/JB 02_R04ddf

55. Jen C. K., Nguyen K. T., Legoux J. G., Ihara I., Hegert H. Novel clad ultrasonic buffer rods for the monitoring of industrial materials processing. NDT net. April 1999. Vol. 4. No.4. P.1-8.

56. Etalon - Innovative piezo transducers. High temperature $900^{\circ} \mathrm{F}$ $\left(482^{\circ} \mathrm{C}\right)$. Continuous transducers. http;//www.etaloninc.com/products.htm

57. Modern ultrasonic transducers. ULTRAN. www.ultranlabs.com

58. Sigma transducers. High temperature applications transducers. http://www.sigmatx.com/high_temp.htm

59. Hagisonic. Ultrasonic transducers. http://www.hagisonic.co.kr/english-pro/eng.pdf

60. Imasonic. Ultrasonic transducers and solutions. High temperature inspection. http://www.imasonic.com

61. Splitt G. Ultrasonic probes for special tasks-the optimum probe for each application. NDTnet. September 1996. Vol. 1. No.09. P.1-5.

62. Optel. Ultrasonic technology. High temperature transducers. http://www.optel.pl/manual/english/temp.htm

63. Rajendran A., Asokane C., Elumalai G. and Swaminathan K. Development of an ultrasonic under-sodium scanner for the fast breeder test reactor. NDT in Nuclear Industry, Proceedings of the 14 th World Conf. on Non-destructive Testing. New Delhi, 8-13 December 1996. Vol. 2, P. 349-352.
64. Kirk K. J., McNab A., Hall A. C. I. and Hayward G. Ultrasonic arrays for monitoring cracks in an industrial plant at high temperatures. IEEE Transactions on Ultrasonics, Ferroelectrics, and Frequency Control. March 1999. Vol. 46. No. 2. P. 311-319.

65. Kobayashi M., Jen C. K., Ono Y. and Kruger S. Lead-free thick piezoelectric films as miniature high temperature ultrasonic transducers. IEEE Ultrasonics Symposium. 2004. P. 910-913.

66. Kobayashi M., Jen C. K., Ono Y. and Moisan J. F. Integratable high temperature ultrasonic transducers for NDT of metals and industrial process monitoring. CINDE Journal. 2005. Vol. 26. No.2. P.5-11.

67. Kobayashi M. and Jen C. K. Piezoelectric thick bismuth titanate/PZT composite film transducers for smart NDE of metals. Smart Mat. and Structures. 2004. Vol. 13. P. 951-956.

68. Butler B., Palmer S. B., Primavesi. G. J. Techniques for the generation of ultrasound for extended periods at high temperatures. Ultrasonics. Vol. 17, Nov. 1979. P. 249-254.

69. Thermocoax. Mineral insulated signal transmission cables. http://www.thermocoax.com

70. Using diffusion bonding in making piezoelectric actuators http://www.nasatech.com/Brirfs/May03/MSC22886.html

71. High temperature amuminum nitride packaging. CTS technical paper. www.ctscorp.com/techpapers/ctshightemp.pdf

72. Choudhury D., Lawyer Ph. H., Foschaar J. A., Wetzel M. D. and Rensch D. B. A solder-free interconnect approach for integrating millimeter wave high-power devices with planar circuitry. IEEE Transactions on Advanced Packaging. November 2003. Vol. 26. No.4. P. 417-424.

R. Kažys, A. Voleišis, B. Voleišienè

\section{Aukštatemperatūrių ultragarsinių keitikliụ apžvalga}

Reziumè

Aukštatemperatūriai ultragarsiniai keitikliai šiuolaikiniame moksle ir pramonèje užima vis svarbesnę vietą. Jų reikiamų parametrų i̇vairovė yra didžiulè ir priklauso nuo taikymo srities. Pagrindinis keitiklio elementas yra aukštatemperatūris pjezoelektrikas, skirtas darbui net iki $700{ }^{\circ} \mathrm{C}$ temperatūroje. Straipsnyje apžvelgiama per 10 pjezoelektrikų ir pateikiami svarbiausieji jų parametrai.

Esminè problema - kaip užtikrinti akustini kontaktą tarp pjezoelektriko ir metalinio protektoriaus plačiame temperatūrų intervale. Vienas perspektyviausiu metodų iš daugybès kitu yra difuzinis sujungimas aukso pagrindu, naudojant dideli slègi, temperatūra ir ultragarso energija. Šis metodas taikomas ir straipsnio autorių. Aptariami autoriu pasiekimai pasauliniame kontekste.

Nagrinejjamos įvairiausios tarptautinèje literatūroje skelbtos mokslininku sukurtos keitiklių konstrukcijos: tiesioginio kontakto, bangolaidiniai, integruotieji, kompozitiniai ir kt. Parodoma, kad komerciniai žinomų pasaulinių firmų keitikliai yra ribotų charakteristikų ir dažnai netenkina eksperimentuotojų. Išvadose pateikiama siūlymų dèl aukštatemperatūrių keitiklių konstrukcijos.

Pateikta spaudai 20080625 